\title{
Mexican National IHP Committee main activities
}

\section{VICTOR BOURGUETT ORTIZ}

Mexican Institute of Water Technology, Paseo Cuauhnáhuac 8536, Jiutepec, Morelos, México vborguett@tlaloc.imta.mx

The Mexican National Committee was created on 26 June 1975, during the first session of the Intergovernmental Council of the IHP. Its headquarters reside in the Mexican Institute of Water Technology in Jiutepec, in the state of Morelos.

The Mexican National IHP Committee has a website for disseminating technical information among Mexican water officials and other stakeholders.

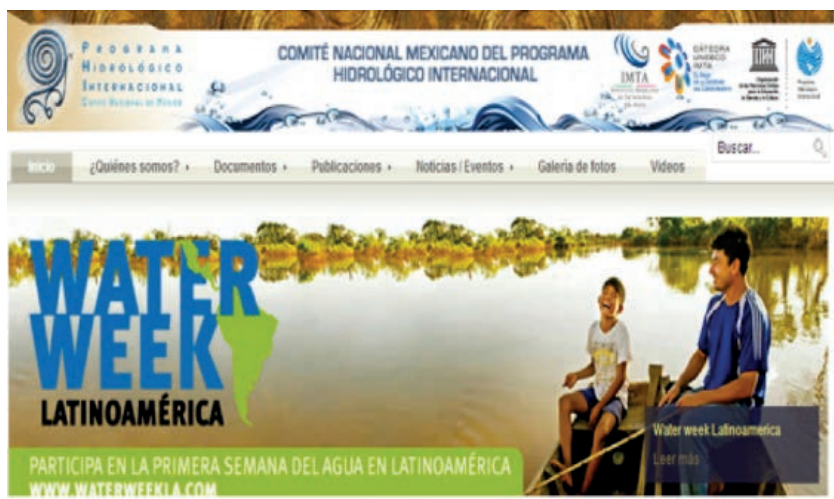

Four potamology seminars were organized with the aim to assess and encourage progress in hydrological research in the areas of river mechanics, surface and groundwater hydrology, environmental hydraulics, water resources development and planning of irrigation engineering, and stochastic hydraulic and hydrology computational systems.

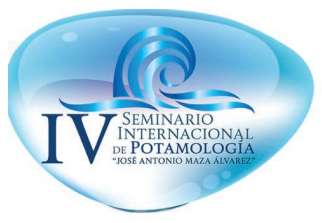

México participated in the development of the arid zone maps for Mexico and Central and South America according to FAO standards and to the methodology of the University of Chile.

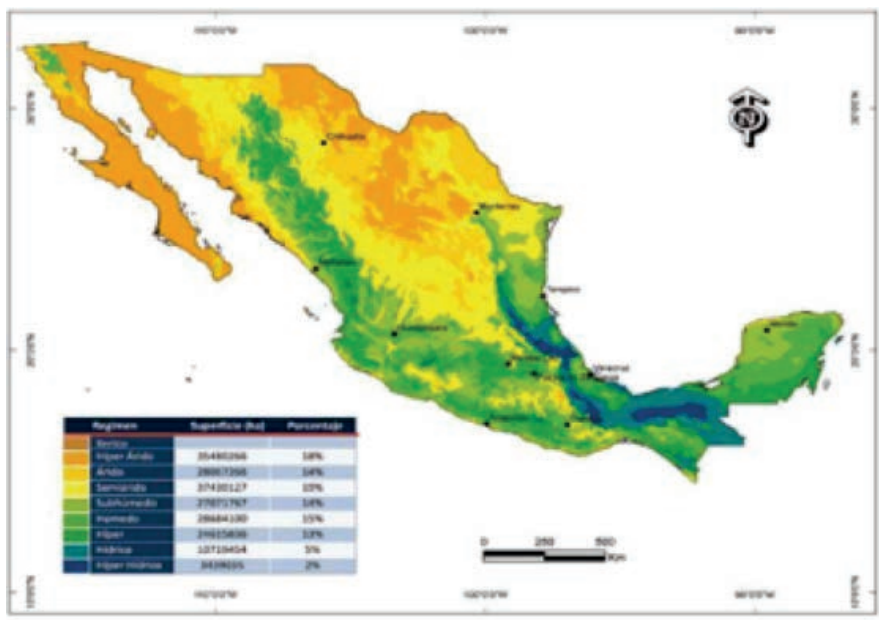


During the period between 2008 and 2012, Mexico's HELP programme collected and updated the information about two important basins: Lerma-Chapala and Patzcuaro.

The UNESCO-IMTA Chair "Water in the Knowledge Society" has the purpose of sharing knowledge and information about water, so that society can lean about the themes related to water resources. Some of the activities carried out were seminars, congresses, publications and a web site. Notable among these activities are: the International Seminar on Water Governance: From Concept to Implementation, annual seminars on the dialogue about the human right to water, and the annual seminar on water and the knowledge society: Points of View on Water-related Governance and Public Policies.

For more information visit www.atl.org.mx.

\section{Books published}

Water culture: This book is a compilation of water-related indigenous symbolism and worldviews in a context of the cultural diversity in Mesoamerica.

PCCP (From Potential Conflict to Cooperation Potential): This book analyses continuities and ruptures that occur from conflicts as part of water governance and the limitations or setbacks in our decentralized watershed management model.

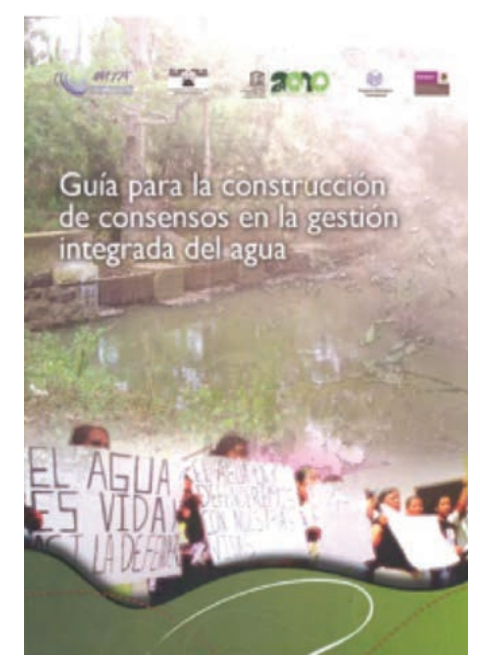

GWADI: The book on climate change and sustainable development for Latin America and the Caribbean.

ISARM (Internationally Shared Aquifer Resources Management programme): Mexico participated in the edition of the book "Transboundary Aquifer systems in America", a regional assessment of the geographical interaction between the environment and groundwater resources.

Water education: The purpose of this guide is to foster a better understanding between the state and water users in a basin. It promotes better decision-making processes and a more responsible participation in water issues. Its main objective is to develop an educational tool to develop skills in environmental education. 